\title{
Unconventional Myosin-XVIIIa
}

National Cancer Institute

\section{Source}

National Cancer Institute. Unconventional Myosin-XVIIIa. NCI Thesaurus. Code C98028.

Unconventional myosin-XVIIIa (2054 aa, $233 \mathrm{kDa}$ ) is encoded by the human MYO18A

gene. This protein may play a role in the shape and function of the Golgi apparatus. 